\title{
$\mathrm{PCR}$ 을 이용한 경북 동부지역 소의 러시아범안열원충 감염률 조사
}

\author{
서민구 • 도재철 · 조민희 - 서희진 ${ }^{1} \cdot$ 김중규 $^{1} \cdot$ 김영환 $^{2} \cdot$ 박노찬 $^{2} \cdot$ 곽동미 $^{3 *}$ \\ 경북가축위생시험소 동부지소, ${ }^{1}$ 경북가축위생시험소 북부지소, ${ }^{2}$ 경북가축위생시험소, ${ }^{3}$ 경북대학교 수의과대학
}

(접수 2011. 8. 23; 수정 2011. 9. 7; 게재승인 2011. 9. 9)

\section{Prevalence of Theileria sergenti infection in cattle of eastern areas in Gyeongbuk province by PCR}

\author{
Min-Goo Seo, Jae-Cheul Do, Min-Hee Cho, Hee-Jin Seo ${ }^{1}$, Joong-Kew Kim ${ }^{1}$, \\ Young-Hoan Kim², No-Chan Park ${ }^{2}$, Dong-Mi Kwak ${ }^{3 *}$ \\ East-Branch, Gyeongbuk Veterinary Service Laboratory, Gyeongju 780-933, Korea \\ ${ }^{1}$ North-Branch, Gyeongbuk Veterinary Service Laboratory, Andong 760-803, Korea \\ ${ }^{2}$ Gyeongbuk Veterinary Service Laboratory, Daegu 702-210, Korea \\ ${ }^{3}$ College of Veterinary Medicine, Kyungpook National University, Daegu 702-701, Korea
}

(Received 23 August 2011; revised 7 September 2011; accepted 9 September 2011)

\section{Abstract}

This study was performed to determine the prevalence of Theileria sergenti ( $T$. sergenti) in cattle reared in eastern areas of Gyeongbuk province by PCR. Among 443 samples collected from 42 cattle farms, $96(21.7 \%)$ samples from $13(31.0 \%)$ farms were positive for T. sergenti. By regions, 87 (26.6\%) out of 327 cattle in Gyeongju, 8 (9.5\%) out of 84 cattle in Pohang, and $1(3.1 \%)$ out of 32 cattle in Ulleung were positive for $T$. sergenti. T. sergenti infection in dairy cattle (27.9\%) was significantly higher than that in Korean cattle $(9.4 \%, P<0.0001)$. Accordingly, Korean cattle were more resistant to $T$. sergenti infection. Prevalence of $T$. sergenti in cattle was increased with age $(P$ $<0.0001)$. The infection rate in cows $(23.3 \%)$ was significantly higher than that in bulls $(5.0 \%, P$ $<0.01)$. Seasonally, prevalence of $T$. sergenti in cattle was highest in autumn $(32.7 \%, P<0.01)$. Prevalence of $T$. sergenti in grazing cattle $(66.7 \%)$ was significantly higher than that in non-grazing cattle $(15.8 \%, P<0.0001)$. Since prevalence of $T$. sergenti infection is high in cattle reared in eastern areas of Gyeongbuk province, survey on other hemoparasites and appropriate control programs need to be established in this region.

Key words : Theileria sergenti, PCR, Sequencing, Cattle, Gyeongbuk province

\section{서 론}

소 범안열원충증(theileriosis)은 진드기 매개에 의한 원충성 질병으로 소형 피로플라즈마병으로 불리며

\footnotetext{
*Corresponding author: Dong-Mi Kwak, Tel. +82-53-950-7794,

Fax. +82-53-950-5955, E-mail. dmkwak@knu.ac.kr
}

Theileria sergenti, T. mutans, T. parva, T. annulata 등 전 세계적으로 12종이 분포하며(Irvin, 1987), 분류상 첨복포자충문(Apicomplexa), 이형열원충목(Piroplasmida), 범안열원충과(Theileriidae)에 속하고 숙주는 소, 물소, 양, 산양이며 비교적 병원성이 약한 러시아범 안열원충(T. sergenti) 감염증은 우리나라의 소에서 발 
생한다. 병원성이 강한 것은 아프리카 동부지역에서 동안열(East Coast fever)을 일으키는 T. parva가 있으 며 치사율이 $90 \%$ 이상이다(한국수의기생충학교수협 의회, 2005).

T. sergenti는 참진드기과(Ixodidae) 중에 국내에 많 은 3숙주성 진드기인 작은 소진드기(Haemaphysalis longicornis)에 의하여 감염되며(한국수의기생충학교 수협의회, 2005), 태반을 통한 선천적인 감염도 가능 하다(백 등, 1993). 유충과 약충에 의한 전파는 가능 하나 난소 전파(transovarian transmission)에 의한 감염 력은 없고 경발육기 전파를 하는 점이 바베스열원충 (Babesia)과 다른 점이다(이, 2007). Theileria는 진드기 장에서 유성생식을 하여 최종적으로 침샘으로 들어 가 진드기가 숙주에 붙어 흡혈하기를 기다리다 흡혈 을 하면 포자생식을 하며, 포유동물의 체내에서는 무 성생식을 하는데 림프구 내에서 분열생식에 의하여 증식한 다음 적혈구에 침입한다(한국수의기생충학교 수협의회, 2005).

진드기는 사람과 동물에 직간접적인 피해를 유발 하는데 증상으로는 빈혈, 발열, 가축의 증체량과 비 유량의 감소, 독소에 의한 마비, 그리고 면역력 감소 로 인한 2차 질병 유발 등을 일으킨다(전, 1970; 김과 손, 1984 ; 강 등, 1988 ; 이 등, 1994). 범안열원충증은 고열, 빈혈, 황달, 원기 및 식욕 감퇴, 쇠약을 동반한 만성소모성 질병으로 다른 질병과 복합 발생하거나 여러 가지 스트레스를 받으면 원충의 감염률이 증가 하여 심한 임상증상을 나타내어 축산농가의 경제적 인 피해가 크며 심할 경우 폐사를 유발하기도 한다 (Takahashi, 1976). 비장의 종대, 황달, 혈색소 뇨를 특 징으로 하는 대형 피로플라즈마병인 바베스열원충증 (babesiosis)과는 차이가 있다(한국수의기생충학교수 협의회, 2005).

국내의 T. sergenti 감염은 진드기 매개이므로 방목 장에서 사육되고 있는 소에서 높게 나타나며(전, 1970 ; 이와 김, 1987 ) 감염률은 $35 \sim 100 \%$ 정도로 심 한 편이며 그 중 30 50\% 정도가 발병하고, 특히 늦 봄부터 초가을까지 많이 발생하며 한우보다는 젖소, 성우보다는 어린 소에서 피해가 크다(백 등, 1993; 채 등, 1996; 이, 2006; 서와 장, 1982; Song과 Sang, 2003; 최 등, 1997; Jeong 등, 2003; 장과 서, 1990).

현미경적 진단법은 혈액도말표본을 Giemsa 염색하 여 관찰하는 방법이 있으나 불현성 감염이 많아서 원 충의 감염률이 낮을 때는 발견하기 어렵고 시간이 오 래 걸리는 단점이 있다. 혈청학적 진단법은 겔침강반
응, 간접형광항체법, ELISA 등(Higuchi 등, 1979; 전과 김, 1997)이 있고 최근에는 유전공학적 기법으로 DNA probe를 이용한 Southern hybridization법, dot blot hybridization법 등이 있으나 단계가 복잡하고 시간이 오래 걸리며 고도의 기술이 필요하기 때문에(Hirano 등, 1991; Kajiwara 등, 1990) 특이성과 민감성이 높고 신속하며 정확한 PCR 기법이 많이 이용되고 있다(채 등, 1996; 최 등, 1997).

경북 동부지역 소 사육현황은 2009년 6월 현재 경 주지역이 한우 5,712호/63,820두, 젖소 227호/14,374 두, 포항지역이 한우 1,571 호/21,748두, 젖소 43호/ 1,799 두, 그리고 울릉지역이 한우 62호/716두를 사육 하고 있어 국내의 다른 지역에 비하여 가축의 사육규 모가 비교적 큼에도 T. sergenti 감염에 대한 지속적이 고 체계적인 조사가 이루어지지 못하였다. 따라서, 이 연구에서는 PCR 기법을 이용하여 경북 동부 지역 한우와 젖소에서의 연령별, 성별, 계절별, 사육형태별 T. sergenti 감염상태를 파악하여 예방 및 치료를 위한 효과적인 대책을 세우는데 기여하고자 하였다.

\section{재료 및 방법}

\section{혈액 시료 및 DNA 분리}

시험에 사용한 시료는 지역별, 농가별, 두수별 역 학적 상황을 고려하여 2009년 3월부터 11월까지 경 북 동부지역인 경주, 포항, 울릉에서 사육되고 있는 총 443두의 소를 선정하였으며, DNA 분리를 위하여 sodium heparin (BD Vacutainer ${ }^{\circledR}$, USA) 처리한 전혈을 사용하였다. 시판 중인 $\mathrm{G}-\mathrm{spin}^{\mathrm{TM}} \mathrm{Genomic} \mathrm{DNA} \mathrm{Ex}-$ traction Kit (Intron Biotechnology, Korea)를 사용하여 전혈 $300 \mu \mathrm{l}$ 에서 $\mathrm{DNA}$ 를 분리하여 $-20^{\circ} \mathrm{C}$ 에 냉동보관 하였다.

\section{$\mathrm{PCR}$ 검사}

유전자 증폭과정은 채 등(1996)의 방법에 따라 primer를 제작하고 반응조건을 동일하게 하여 이번 실 험에 맞게 사용하였다. 시판되는 AccuPower ${ }^{\mathrm{TM}} \mathrm{PCR}$ Premix Kit (Bioneer, Korea)를 사용하였는데 10 pmole/ $\mu \mathrm{l}$ 의 KTS1-R forward primer (5'-CCTCTTGAAGTCATCCATGT-3')와 KTS1-R backward primer (5'-CACTGAGCTGGAAAGAGCTA-3') 각각 $1 \mu$ l와 시료 DNA 
$1 \mu \mathrm{l}$ 를 혼합하고 멸균 증류수를 첨가하여 총량이 $20 \mu \mathrm{l}$ 가 되도록 하였다. 예상증폭 크기는 $128 \mathrm{bp}$ 이며 반응 조건은 predenaturation을 $96^{\circ} \mathrm{C}$ 에서 3 분간 실시 후 denaturation은 $96^{\circ} \mathrm{C}$ 에서 30 초, annealing은 $60^{\circ} \mathrm{C}$ 에서 1 분, polymerization은 $72^{\circ} \mathrm{C}$ 에서 1 분간 총 35 cycle로 증폭을 하고 그 후 $72^{\circ} \mathrm{C}$ 에서 3 분간 post polymerization을 실시 하였다(채 등, 1996). 유전자 증폭기는 T Professional Thermocycler (Biometra, Germany)를 사용하였다.

\section{증폭된 DNA 산물의 분석}

증폭된 산물의 확인을 위하여 $\mathrm{PCR}$ 산물 $10 \mu \mathrm{l}$ 를 $2 \%$ agarose gel에 $100 \mathrm{~V}$ 로 30 분간 전기영동을 한 후 $0.5 \mu \mathrm{g} / \mathrm{ml} /$ ethidium bromide (Bioneer, Korea)를 처치하 여 UV transilluminator로 관찰하였다. 증폭된 DNA 산 물의 크기 확인을 위하여 $100 \mathrm{bp} \mathrm{DNA} \mathrm{ladder(Intron}$ Biotechnology, Korea)를 size marker로 이용하였다.

\section{DNA sequencing}

유전자 증폭산물을 시판 중인 AccuPrep ${ }^{\circledR} \mathrm{Gel}$ Purification Kit (Bioneer, Korea)를 이용하여 DNA fragment 를 정제하여 염기서열 분석에 사용하였다. Sequencing (Bioneer, Korea) 과정은 정제된 DNA와 KTS1-R forward primer, KTS1-R backward primer와 Big- Dye ${ }^{\mathrm{TM}}$ Terminator v3.1 sequencing kit (Applied Biosystems, USA)를 이용하여 automatic sequencer인 ABI3730 DNA Analyzer (Applied Biosystems, USA)로 수행하였 다. 조사된 염기서열의 multiple sequence alignment는 ClustalW v2.0.12 Multiple Sequence Alignments soft-

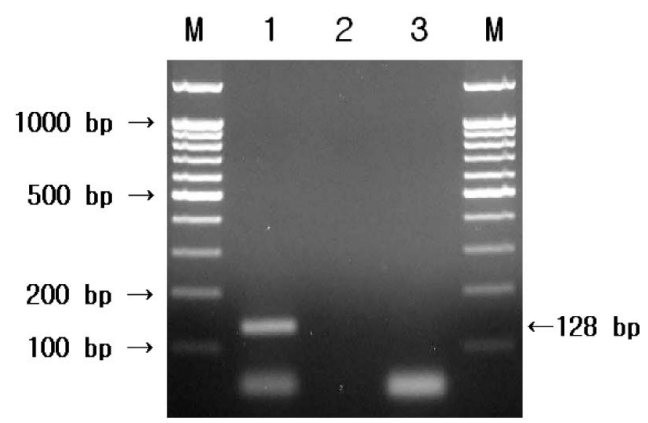

Fig. 1. DNA amplified from Theileria sergenti gene fragment (128 bp) in cattle by PCR. Lane M: 100 bp DNA ladder, lane 1: positive sample with primers, lane 2: positive sample without primers, lane 3: negative sample with primers. ware를 이용하여 비교하였다.

\section{통계학적 분석}

각각의 PCR 반응에서 얻은 결과들을 품종별, 연령 별, 성별, 계절별, 사육형태별을 기준으로 상호 비교 분석하였다. 여기서 얻은 수치들의 유의성 검증을 위 하여 SPSS (Statistical Package for the Social Sciences) V.12.0을 이용하여 chi-square test를 실시하였다.

\section{결 과}

\section{$\mathrm{PCR}$ 결과}

T. sergenti 감염이 확인된 개체에서는 $128 \mathrm{bp}$ 의 증 폭산물이 확인되었으며(Fig. 1) 경북 동부지역에서 사 육되는 소의 T. sergenti 양성률은 검사된 총 42호 443 두 중 양성 13호(31.0\%) 96두(21.7\%)를 나타내었고, 지역별로는 경주지역 29호 327 두 중 양성 10 호 (34.5\%) 87두(26.6\%), 포항지역 10호 84두 중 양성 2 호(20.0\%) 8두(9.5\%), 울릉지역 3호 32두 중 양성 1호 (33.3\%) 1두(3.1\%)를 나타내었다(Table 1).

품종별 양성률은 젖소 294두 중 양성 82두(27.9\%), 한우 149 두 중 양성 14 두 $(9.4 \%)$ 를 나타내어 젖소가 한 우보다 유의적으로 높게 나타났다 $(P<0.0001$, Table 2).

연령별 양성률은 2 세 이하 162 두 중 양성 18 두 $(11.1 \%), 3$ 세에서 5세까지 236두 중 양성 62 두 (26.3\%), 6세에서 7세까지 36두 중 양성 11두(30.6\%), 8 세 이상 9두 중 양성 5 두 $(55.6 \%)$ 를 나타내어 나이 의 증가에 따라 유의적으로 증가하였다 $(P<0.0001$, Table 3).

Table 1. Prevalence of Theileria sergenti infection in cattle reared in eastern areas of Gyeongbuk province by PCR

\begin{tabular}{llcc}
\hline \multirow{2}{*}{ Area } & & \multicolumn{2}{c}{ No. of cattle (\%) } \\
\cline { 3 - 4 } & & Tested & Positive \\
\hline \multirow{2}{*}{ Gyeongju } & Farms & 29 & $10(34.5)$ \\
& Heads & 327 & $87(26.6)$ \\
Pohang & Farms & 10 & $2(20.0)$ \\
& Heads & 84 & $8(9.5)$ \\
\multirow{4}{*}{ Totaleung } & Farms & 3 & $1(33.3)$ \\
& Heads & 32 & $1(3.1)$ \\
& Farms & 42 & $13(31.0)$ \\
& Heads & 443 & $96(21.7)$ \\
\hline
\end{tabular}


Table 2. Prevalence of Theileria sergenti infection in cattle reared in eastern areas of Gyeongbuk province according to breed by PCR

\begin{tabular}{lll}
\hline \multirow{2}{*}{ Breed } & \multicolumn{2}{c}{ No. of cattle (\%) } \\
\cline { 2 - 3 } & Tested & Positive \\
\hline Dairy cattle & 294 & $82(27.9)^{*}$ \\
Korean cattle & 149 & $14(9.4)^{*}$ \\
Total & 443 & $96(21.7)$ \\
\hline
\end{tabular}

*Significant statistical difference $(P<0.0001)$.

Table 3. Prevalence of Theileria sergenti infection in cattle reared in eastern areas of Gyeongbuk province according to age by PCR

\begin{tabular}{ccc}
\hline \multirow{2}{*}{ Age (year) } & \multicolumn{2}{c}{ No. of cattle $(\%)$} \\
\cline { 2 - 3 } & Tested & Positive \\
\hline$\leq 2$ & 162 & $18(11.1)^{*}$ \\
$3 \sim 5$ & 236 & $62(26.3)^{*}$ \\
$6 \sim 7$ & 36 & $11(30.6)^{*}$ \\
$8 \leq$ & 9 & $5(55.6)^{*}$ \\
Total & 443 & $96(21.7)$ \\
\hline
\end{tabular}

*Significant statistical difference $(P<0.0001)$.

Table 4. Prevalence of Theileria sergenti infection in cattle reared in eastern areas of Gyeongbuk province according to sex by PCR

\begin{tabular}{ccc}
\hline \multirow{2}{*}{ Sex } & \multicolumn{2}{c}{ No. of cattle (\%) } \\
\cline { 2 - 3 } & Tested & Positive \\
\hline Bulls & 40 & $2(5.0)^{*}$ \\
Cows & 403 & $94(23.3)^{*}$ \\
Total & 443 & $96(21.7)$ \\
\hline
\end{tabular}

*Significant statistical difference $(P<0.01)$.

성별에 따른 양성률은 수소 40 두 중 양성 2 두 $(5.0 \%)$, 암소 403 두 중 양성 94 두 $(23.3 \%)$ 를 나타내어 암소가 수 소보다 유의적으로 높게 나타났다 $(P<0.01$, Table 4$)$.

계절에 따른 양성률은 봄에 채혈한 36 두 중 양성 2 두 $(5.6 \%)$, 여름에 채혈한 303두 중 양성 60 두 $(19.8 \%)$, 가을에 채혈한 104 두 중 양성 34 두(32.7\%)를 나타내 어 봄에서 가을로 갈수록 유의적으로 높게 나타났다 $(P<0.01$, Table 5).

농장의 사육형태에 따른 양성률은 방목지역 소 51 두 중 양성 34두(66.7\%), 비방목지역 소 392두 중 양 성 62 두(15.8\%)를 나타내어 방목지역의 소가 비방목 지역의 소보다 유의적으로 높게 나타났다 $(P<0.0001$, Table 6).
Table 5. Prevalence of Theileria sergenti infection in cattle reared in eastern areas of Gyeongbuk province according to seasons by PCR

\begin{tabular}{lcl}
\hline \multirow{2}{*}{ Season } & \multicolumn{2}{c}{ No. of cattle (\%) } \\
\cline { 2 - 3 } & Tested & Positive \\
\hline Spring & 36 & $2(5.6)^{*}$ \\
Summer & 303 & $60(19.8)^{*}$ \\
Autumn & 104 & $34(32.7)^{*}$ \\
Total & 443 & $96(21.7)$ \\
\hline
\end{tabular}

*Significant statistical difference $(P<0.01)$.

Table 6. Prevalence of Theileria sergenti infection in cattle reared in eastern areas of Gyeongbuk province according to farming styles by PCR

\begin{tabular}{lcl}
\hline \multirow{2}{*}{ Farming style } & \multicolumn{2}{c}{ No. of cattle (\%) } \\
\cline { 2 - 3 } & Tested & Positive \\
\hline Grazing & 51 & $34(66.7)^{*}$ \\
Non-grazing & 392 & $62(15.8)^{*}$ \\
Total & 443 & $96(21.7)$ \\
\hline
\end{tabular}

*Significant statistical difference $(P<0.0001)$.

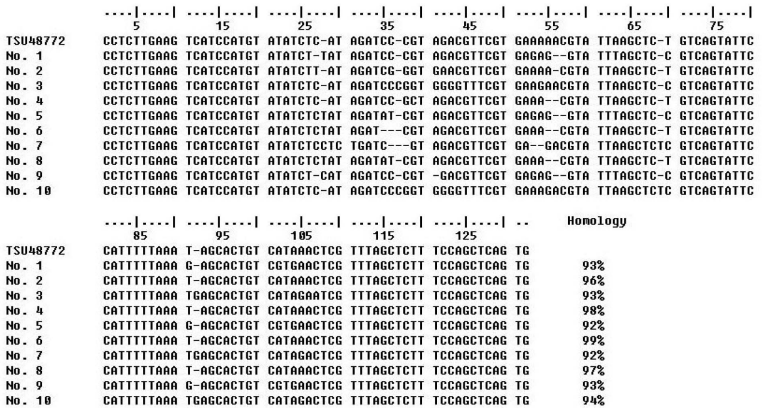

Fig. 2. Nucleotide sequence homology in Theileria sergenti genomic DNA among KTS1-R (TSU48772) and field strains (Nos. 1 10) from cattle. Gaps indicated with (-) express mismatching nucleotides.

\section{DNA sequencing 결과}

T. sergenti 양성을 나타내는 13호 96 두 중 농장별 1 두를 임의로 선택하여 총 10 호 10 두의 PCR 증폭산물 에서 염기서열을 분석한 결과 최종적으로 T. sergenti 감염이 확인되었다. T. sergenti genomic sequence KTS1-R (GenBank Accession No. U48772)과 10개의 시료 (Nos. 1 10)을 각각 비교 분석하여 유사성을 확인해 본 결과 염기서열이 92 99\%의 높은 homology를 나 타내었다(Fig. 2). 


\section{고 찰}

우리나라는 산악지역이 대부분인 지리적, 기후적 여건으로 봄부터 가을까지 진드기가 전국적으로 서 식하며 계절에 따른 출현 빈도가 다르므로 진드기 매 개성 질병의 발현 정도도 달라질 수 있다(이, 2006). 소의 적혈구에 기생하는 주혈원충은 초방목우의 목 야위생에 매우 문제시되는 전염병이며 피로플라즈마 병으로 불리는 대표적인 것에는 Theileria spp., Babesia spp. 등이 있다(전, 1970). 주혈원충은 소의 적혈구 를 용혈 및 파괴하므로 적혈구 수가 감소하여 빈혈을 일으키며, Theileria spp.의 병원체는 항상 적혈구에 출현하나 Anaplasma spp.와 Babesia spp.의 병원체는 감염초기 적혈구에서 관찰할 수 있지만, 만성기에는 소실되어 관찰하기 어려운 것으로 알려졌다(전, 1970).

범안열원충증의 피해가 문제시되는 국가는 많지만, 그 중 T. sergenti는 한국, 중국, 러시아, 일본 등 극동 지역과 동남아시아에서 문제가 되고 있다(채 등, 1994). 국내에서는 매개체인 진드기 중 작은 소진드 기(H. longicornis)에 의해 공통으로 T. sergenti, $A$. marginale, B. ovata 등이 개별 혹은 혼합 감염되어 증 상이 나타나는 경우가 많아 그에 따른 감별진단과 치 료대책이 필요하다(서와 장, 1982).

대부분 지역에서 진드기에 오염된 초지에 소를 방 목시키면 진드기의 초지오염도에 따라 차이가 있지 만, 방목 후 4 5주째를 전후하여 T. sergenti에 전부 감염되는 시기에 도달하는 것을 알 수 있다(서와 장, 1982). 또한, 오염초지에서 채취한 청초 또는 건초 등 을 사사기간 중의 소에 급여할 때 그 풀 사료에 묻어 온 진드기에 의한 감염도 문제가 되는데, 겨울동안 축사 온도나 습도 등 조건이 맞으면 이 기간에도 진 드기가 바로 활동하고 흡혈할 수 있어 사사기간 중의 감염도 주의해야 한다(한국수의기생충학교수협의회, 2005).

이번 조사에서 사용된 primer는 채 등(1996)에 의해 사용된 것으로 $128 \mathrm{bp}$ 에서 증폭되어 T. sergenti의 DNA에만 특이하게 반응했으며, 소의 백혈구와 신장 세포 DNA에서는 증폭되지 않았고 $10 \mu \mathrm{l}$ 의 혈액 시료 에서 적혈구 내 감염률 $0.00029 \%$ (원충 164 개)까지 검 출(채 등, 1996)할 수 있어 민감도가 높은 것으로 조 사되었기에 이 연구에서 사용하였다.

외국에 있어 소의 T. sergenti 감염률은 Tanaka 등 (1993)은 일본에서 $82 \%$, Inoue 등(2001)은 캄보디아에
서 $50.4 \%$, 베트남에서 $27.5 \%$ 의 수치를 나타내었다. 국내의 경우 감염률을 연도별로 비교해보면, 한과 김 (1965)은 1964년 한우에서 $60.2 \%$, 손(1964)은 경북의 한우에서 $94.4 \%$, 전(1970)은 1969년 서울의 한우와 젖소에서 $93.5 \%$ 의 수치를 나타내었다. 장(1974)은 한 우와 도입우에서 $81.0 \%$, 전(1978)은 서울의 한우에서 $58.4 \%$ 의 수치를 나타내었고, 서와 장(1982)은 전국의 도입우에서 $79.2 \sim 100 \%$, 이와 김(1987)은 전북의 젖 소에서 $100 \%$ 의 수치를 나타내었다. 장과 서(1990)는 경남지역의 한우와 도입우에서 $71.8 \%$, 백 등(1993)은 한우에서 제주도 $100 \%$, 경기도 $35 \%$, 전라북도 $50 \%$, 채 등(1996)은 전북의 한우에서 $72.8 \%$, 최 등(1997)은 한우에서 $88.7 \%$ 의 수치를 나타내었다. 최근, Jeong 등 (2003)은 2002년 한우와 젖소에서 $35.6 \%$, Song과 $\operatorname{Sang}(2003)$ 은 충남의 한우에서 $67.8 \%$, 이(2006)는 2004년 제주도의 한우에서 $76.3 \%$, 젖소에서 $98.3 \%$ 의 수치를 나타내어 전국적으로 다양한 분포를 보였다.

경북 동부지역에서 사육되고 있는 소의 T. sergenti 감염률이 농가 호수별로는 $31.0 \%$, 두수별로는 $21.7 \%$ 를 나타내었고, 각 지역의 두수별로는 경주지역 $26.6 \%$, 포항지역 $9.5 \%$, 울릉지역 $3.1 \%$ 를 나타내었다. 과거 경북 지역은 손(1964)이 조사한 한우에서 $94.4 \%$ 의 감염률을 나타내었고 그 이후 경북 지역에서는 연 구가 없다가 2009년 이번 조사에서 $21.7 \%$ 의 수치를 나타내어 과거 조사보다 감소한 수치를 보였다. 또한, 과거 국내에서 조사된 전체 감염률과 비교를 했을 때 도 이번 조사 결과는 $21.7 \%$ 로 낮은 수치를 보였는데 이것은 총 검사두수 443 두 중 방목지역 소가 51 두로 적은 데 비해 비방목지역 소가 392두로 많았기 때문 에 검사두수 대부분이 진드기에 의한 감염기회가 적 어 감염률도 낮은 것으로 판단된다. 과거의 조사에서 는 대부분 방목지역 소들을 대상으로 감염률 조사를 해서 그 결과가 이번 실험보다 높았던 것으로 보이 며, 이처럼 국내에서 진드기 서식이 낮은 내륙지역에 서는 감염강도가 $31.3 \sim 40$ (parasitaemia/1,000 RBC)을 나타내어도 발병 없이 내과하는 것으로 알려져 있다 (서와 장, 1982).

품종별 양성률 조사 결과 젖소 $27.9 \%$, 한우 $9.4 \%$ 의 수치로 젖소가 한우보다 높게 나타났는데, 이 결과는 일반적으로 도입우는 한우보다 주혈원충성 질병에 감 수성이 높아서(서와 장, 1982) 도입우에서 감염률과 감 염강도가 높게 나타나며(장과 서, 1990) 빈혈 소견도 한우보다 젖소에서 높게 나타나는 것(전, 1970)과 같이 한우가 젖소보다 저항성이 높은 것으로 조사되었다. 
연령별 양성률 조사 결과 2 세 이하 $11.1 \%, 3$ 세에서 5 세까지 $26.3 \%, 6$ 세에서 7 세까지 $30.6 \%, 8$ 세 이상 $55.6 \%$ 의 수치를 나타내어 Song과 Sang (2003)이 조사 한 3세 미만 $61.8 \%, 3$ 세 이상 $75.0 \%$ 의 수치와 같이 나이가 많은 개체일수록 누적감염이 증가하여 지속 감염상태를 나타내었다.

성별에 따른 양성률 조사 결과 수소 $5.0 \%$, 암소 $23.3 \%$ 의 수치를 나타내어 Song과 Sang (2003)이 조사 한 수소 $40.0 \%$, 암소 $70.3 \%$ 의 수치와 같이 암소가 더 높게 나와서 감염에 있어 암소가 수소보다 감수성이 더 높은 것으로 보인다. 하지만 이번 조사 역시 총 검 사두수 443 두 중 암소가 403두로 많은 것과 비교했을 때 수소가 40 두밖에 되지 않으므로 앞으로의 연구에서 는 비슷한 검사두수의 비교가 필요하다고 판단된다.

계절에 따른 양성률 조사 결과 봄은 $5.6 \%$, 여름은 $19.8 \%$, 가을은 $32.7 \%$ 의 수치를 나타내어, 전(1970)이 조사한 봄 $90.7 \%$, 여름 $92.7 \%$, 가을 $97.4 \%$ 의 감염 수 치와 혈액학적 검사 결과인 백혈구 수가 증가하고 적 혈구 수가 감소하는 여름에 감염률과 중증감염 예가 다소 많은 것과 비교했을 때 봄에서 가을로 갈수록 수치가 증가한 것은 비슷하였다. 하지만 전(1978)이 조사한 봄 $56.2 \%$, 여름 $64.2 \%$, 가을 $57.3 \%$ 의 감염 수 치, 이(2006)가 조사한 5월 55.1\%, 7월 91.0\%, 9월 $78.9 \%, 11$ 월 $97.2 \%$ 의 감염 수치, 장과 서(1990)가 조 사한 봄 $77.0 \%$, 여름 $73.3 \%$, 가을 $65.3 \%, 12$ 월 $38.5 \%$ 의 감염 수치와 $5 \sim 8$ 월은 다른 달에 비해 감염 강도 가 높은 수치를 보이는 것과 비교했을 때는 계절별로 는 약간씩의 차이를 보였다. 이와 같은 결과는 한우 에 기생하는 H. longicornis 진드기의 월별 성장이 3 월 부터 점차 증가하여 7월에 최고 기생력을 보인 후 8 월부터는 점차로 감소하여(한 등, 1966) 여름에 활발 하던 진드기의 활동이 겨울이 되면서 저하되어 적혈 구계의 변화에 직접적인 영향을 미칠 수 있는 진드기 매개 주혈원충성 질병으로부터 어느 정도 회복되었 기 때문으로 추정한다(이, 2006).

농장의 사육형태에 따른 양성률은 방목지역 소 $66.7 \%$, 비방목지역 소 $15.8 \%$ 의 수치를 나타내어 Song 과 Sang(2003)이 조사한 방목지역 소 $76.1 \%$, 비방목 지역 소 $51.0 \%$ 의 수치와 같이 방목 사육하는 소에서 높게 나타났다. 이처럼 방목지역의 소는 초지에 있는 진드기에 장시간 노출된 환경에서 사육되고 있고 그 만큼 진드기에 의한 T. sergenti 감염 기회도 높을 것 으로 추정하고 있다(Yamane 등, 2001).

경북 동부지역의 소에 감염된 T. sergenti의 염기서열
을 농장별로 비교 분석한 결과, T. sergenti genomic sequence KTS1-R (GenBank Accession No. U48772)과 시 료(Nos. 1 10)의 nucleotide 서열이 $92 \sim 99 \%$ 의 높은 homology를 나타내어 각 농장의 개체별로 약간씩의 차 이는 있었지만 거의 일치하는 것을 확인할 수 있었다.

이번 실험 결과를 종합해 보면 소의 T. sergenti 감 염이 전국적으로 상재되어 있으며 방목지역에서 높 게 나타나고 한우가 저항성이 높으며 진드기 매개에 의한 계절적인 영향이 있다는 것을 알 수 있다. 향후 추가적인 조사가 이루어질 경우 비교 대상 개체의 일 정한 분포, 각기 다른 allele형인 T. sergenti Ikeda type, T. sergenti Chitose type, T. buffeli Warwick type 등의 비교(Kakuda 등, 1998), 다른 진드기매개성 질병인 Anaplasma spp., Babesia spp. 등의 개별 혹은 복합 감 염 비교, 방목우에 기생하는 진드기의 종 분류 및 주 혈원충 감염 조사, 소의 계절적인 혈액학적 변화상 등을 비교한다면 더욱 의미 있을 것으로 추정된다. 현재까지 국내에서 사용되는 치료약제는 Pamaquine, Primaqiune, Berenil (diminazene aceturate), Ganaseg (diamidine제) 등이 있는데 적내형 원충의 증식억제제로서 만 효과가 있다(한국수의기생충학교수협의회, 2005). 예방 및 치료 프로그램은 제주도의 경우 원충증식억 제 예방프로그램(suppressive chemoprophylaxis program) 이 있고 내륙지역은 전략적 예방프로그램(strategic chemoprophylaxis program) 등이 있으며 살진드기제 사 용, 자연감염 면역형성법, 휴목에 의한 목야청정법, 가을철 단기 방목에 의한 발증의 예방 등도 있다(서 와 장, 1982). 유행지역에서는 임상증상만으로 진단할 수 있지만 이 원충이 다른 미생물의 증식을 억제할 수 있는 것도 고려해야 한다(이, 2007). 따라서 T. sergenti 감염 예방과 근절을 위해서는 방목우에 대한 체 계적이고 전체적인 조사가 지속적으로 이루어져야 할 것이며, 질병에 대한 보다 효과적인 예방 및 치료 법의 개발과 다른 주혈원충의 혼합 감염 방지를 위해 매개체인 진드기의 정기적인 구제가 필요하다고 판 단된다.

\section{결 론}

경북 동부지역에서 $\mathrm{PCR}$ 기법을 이용해 소의 $T$. sergenti 감염률을 조사한 결과 총 42 호 443 두 중 양 성 13호(31.0\%) 96두(21.7\%)를 나타내었다.

지역별로는 경주지역 29호 327 두 중 양성 10 호 
(34.5\%) 87두(26.6\%), 포항지역 10호 84두 중 양성 2 호(20.0\%) 8두(9.5\%), 울릉지역 3호 32두 중 양성 1호 (33.3\%) 1두(3.1\%)로 조사되었다. 품종별로는 젖소 294두 중 양성 82두(27.9\%), 한우 149두 중 양성 14두 $(9.4 \%)$ 를 나타내어 한우가 젖소보다 저항성이 높은 것으로 조사되었다. 연령별로는 2 세 이하 162 두 중 양성 18 두 $(11.1 \%), 3$ 세에서 5세까지 236두 중 양성 62 두 $(26.3 \%), 6$ 세에서 7 세까지 36 두 중 양성 11 두 (30.6\%), 8세 이상 9두 중 양성 5두(55.6\%)를 나타내 어 나이에 따라 증가하였다. 성별로는 수소 40 두 중 양성 2두(5.0\%), 암소 403두 중 양성 94두(23.3\%)를 나타내어 암소가 수소보다 높게 나타났다. 계절별로 는 봄에 채혈한 36 두 중 양성 2 두 $(5.6 \%)$, 여름에 채혈 한 303두 중 양성 60 두 $(19.8 \%)$, 가을에 채혈한 104 두 중 양성 34 두(32.7\%)를 나타내어 봄에서 가을로 갈수 록 높게 나타났다. 농장의 사육형태별로는 방목지역 소 51두 중 양성 34두(66.7\%), 비방목지역 소 392두 중 양성 62 두(15.8\%)를 나타내어 방목지역의 소가 비 방목지역의 소보다 감염이 높은 것으로 조사되었다.

\section{참 고 문 헌}

강영배, 김상희, 장환, 위성환, 이영옥. 1988. Theileria sergenti 야외주에 대한 성상조사: 접종적 비우에 있어서의 혈 액학적 소견 및 Pamaquine 처리효과. 농시논문 30: $17-21$.

김인철, 손제영. 1984. 진드기의 기생이 많은 목장에서 Theileria sergenti 감염유우의 분만후 혈액상 및 비유량의 변동에 관한 연구. 한국동물자원과학회지 26: $137-$ 144.

백병걸, 임병무, 이우종, 김진호, 김병수, 손동수, 이광원. 1993. 신생 송아지에 있어서 Theileria sergenti의 감염에 관 한 연구. 대한수의학회지 33: 665-671.

서명득, 장두환. 1982. 도입우의 진드기매개 주혈원충 감염상 과 Theileria sergenti의 치료예방에 관한 연구. 한국수 의공중보건학회지 6: 33-57.

손제영. 1964. 경북지방을 중심으로한 축우의 Piroplasma병에 관한 연구. 경대논문집 8: 237-272.

이영화. 2006. 제주도에서 사육되는 한우와 젖소의 계절적인 혈액상 변화 및 진드기 매개성 병원체 검출. 전북대 대학원 석사학위청구논문: 1-49.

이주묵, 김명철. 1987. 젖소의 파이로프라스마증의 효과적인 집단검색과 치료방법에 관한 연구. 대한수의학회지 27: 321-330.

이주묵, 권오덕, 채준석, 김명철, 김흥섭, 이성재, 이후식, 노수 일, 김길수. 1994. 호남지역의 양축농가에 있어서 UR 에 대처한 가축의 생산성 향상에 관한 연구. 대한수 의학회지 34: 195-212.
이재구. 2007. 최신수의기생충학. 3판. pp. 591-624. 나눔의 집. 서울.

장동화, 서명득. 1990. 서부 경남지역의 도살축우에 대한 주혈 기생충의 역학적 조사. 대한수의학회지 30: 473-478.

장두환. 1974. Theileriosis(연안열)의 역학적 연구. 연안열의 국 내 현황과 그 매개 참진드기의 생태조사. 대한기생충 학회지 12: 14-20.

전 영. 1970. 국내 소의 주혈원충과 그 혈액학치에 관한 조사 연구. 농사시험연구보고 13: 81-87.

전 영. 1978. 한우의 바베시아와 다이레리아 원충의 감염실 태 조사. 대한수의학회지 18: 23-26.

전 영, 김동성. 1997. 간접형광항체법에 의한 한우 타이레리 아병의 혈청학적 진단에 관한 연구. 농사시험연구보 고 19: 27-32.

채준석, 이주묵, 권오덕, 채건상. 1994. 한우에 감염된 Theileria sergenti merozoite의 순수분리와 genomic DNA probe 에 관한 연구. 대한수의학회지 34: 387-394.

채준석, 이주묵, 권오덕, 박진호, 채건상. 1996. 중합효소연쇄 반응을 이용한 한우에 감염된 Theileria sergenti의 신 속한 검출. 대한수의학회지 36: 195-207.

최은진, 강승원, 권창희, 정우석, 윤용덕, 송희종. 1997. 중합효 소연쇄반응을 이용한 Theileria sergenti의 신속한 검 출. 기생충학잡지 35: 111-118.

한국수의기생충학교수협의회. 2005. 수의기생충학. pp. 323352. 농경애니텍, 서울.

한태우, 김삼기. 1965. 소의 피로플라즈마병의 분포조사 및 인 공감염시험. 농사시험연구보고 8: 109-120.

한태우, 김삼기, 전영. 1966. 한국우에 기생하는 진드기의 종 류 및 분포에 대하여. 농사시험연구보고 9: 91-103.

Higuchi S, Kawamura S, Yasuda Y. 1979. Studies on the isolation and characterization of Theileria antigens: particulary on the applicability to passive hemagglutination test. Kitasato Arch Exp Med 52: 1-14.

Hirano A, Kirisawa R, Matsuba T, Komatsu R, Tanaka M, Takahashi K, Kawakami Y, Onuma M. 1991. Evaluation of high sensitive DNA probe for the detection of Theileria sergenti infection in cattle. J Vet Med Sci 53: 933-935.

Inoue M, Van Nguyen D, Meas S, Ohashi K, Sen S, Sugimoto C, Onuma M. 2001. Survey of Theileria parasite infection in cattle in Cambodia and Vietnam using piroplasm surface protein gene-specific polymerase chain reaction. J Vet Med Sci 63: 1155-1157.

Irvin AD. 1987. Characterization of species and strains of Theileria. Adv Parasitol 26: 145-197.

Jeong W, Kweon CH, Kang SW, Paik SG. 2003. Diagnosis and quantification of Theileria sergenti using TaqMan PCR. Vet Parasitol 111: 287-295.

Kajiwara N, Kirisawa R, Onuma M, Kawakami Y. 1990. Specific DNA probe for the detection of Theileria sergenti infection in cattle. Nihon Juigaku Zasshi 52: 1199-1204.

Kakuda T, Kubota S, Sugimoto C, Baek BK, Yin H, Onuma M. 1998. Analysis of immunodominant piroplasm surface protein genes of benign Theileria parasites distributed in China and Korea by allele-specific polymerase chain 
reaction. J Vet Med Sci 60: 237-239.

Song KH, Sang BC. 2003. Prevalence of Theileria sergenti infection in Korean native cattle by polymerase chain reaction. Korean J Parasitol 41: 141-145.

Takahashi K. 1976. Studies on the infection and immunity of Theileria sergenti. J Coll Dirying 6: 179-248.

Tanaka M, Onoe S, Matsuba T, Katayama S, Yamanaka M, Yonemichi H, Hiramatsu K, Baek BK, Sugimoto C,
Onuma M. 1993. Detection of Theileria sergenti infection in cattle by polymerase chain reaction amplification of parasite-specific DNA. J Clin Microbiol 31: 2565-2569.

Yamane I, Koiwai M, Tsusui T, Hamaoka T. 2001. A survey of Theileria sergenti infection, daily weight gain and conception proportions in 85 herds of grazing heifers in Japan. Vet Parasitol 99: 189-198. 